\title{
Prognostic and predictive implications of Sokal, Euro and EUTOS scores in chronic myeloid leukaemia in the imatinib era-experience from a tertiary oncology centre in Southern India
}

\author{
Lakshmaiah Chinnagiriyappa Kuntegowdanahalli, Govind Babu Kanakasetty, Aditi Harsh Thanky, Lokanatha Dasappa, \\ Linu Abraham Jacob, Suresh Babu Mallekavu, Rajeev Krishnappa Lakkavalli, Lokesh N Kadabur and Rudresha Antapura \\ Haleshappa
}

Department of Medical Oncology, Kidwai Memorial Institute of Oncology, Bengaluru, India

Correspondence to: Aditi Harsh Thanky. Email: aditik2008@yahoo.com

\begin{abstract}
Chronic myeloid leukaemia (CML) is a myeloproliferative disorder. Over the years many prognostic models have been developed to better risk stratify this disease at baseline. Sokal, Euro, and EUTOS scores were developed in varied populations initially receiving various therapies. Here we try to identify their predictive and prognostic implication in a larger population of Indian patients with CML-CP (chronic phase) in the imatinib era.
\end{abstract}

Keywords: CML, Sokal score, Euro score, EUTOS score

Published: 06/10/2016

Received: 29/05/2016

ecancer 2016, 10:679 DOI: 10.3332/ecancer.2016.679

Copyright: (c) the authors; licensee ecancermedicalscience. This is an Open Access article distributed under the terms of the Creative Commons Attribution License (http://creativecommons.org/licenses/by/3.0), which permits unrestricted use, distribution, and reproduction in any medium, provided the original work is properly cited. 


\section{Introduction}

Chronic myeloid leukaemia $(\mathrm{CML})$ is a myeloproliferative disorder with three different phases at presentation. Early chronic phase disease $(C M L-C P)$ is the disease with most favourable outcomes while the advanced accelerated phase $(C M L-A P)$ and the blast phase $(C M L-B P)$ have poorer outcomes with conventional therapy [1].

Over the years many new developments in management have lead to significant improvements in prognosis of the disease starting from oral or intravenous chemotherapy like busulfan, immunotherapy with interferon alpha (IFNa), and most recently introduction of targeted therapy with oral tyrosine kinase inhibitors (TKI).

Many investigators have tried to develop predictive and prognostic models to risk stratify CML-CP at baseline over the years involving varied treatment strategies and patient populations with the help of varied statistical tests and endpoints. Amongst the many scores available, which one will best predict response to current imatinib therapy and prognosticate survival outcome still remains debatable with very limited data available from the Asian population [2-4]. We here try to assess the most widely used prognostic risk models including Sokal relative risk score, Euro relative risk score, and EUTOS (European Treatment and Outcome Study) score in a large cohort of Indian patients and compare their efficacy as a predictive and prognostic tool in the imatinib era.

\section{Methods}

We identified cases of Philadelphia chromosome (Ph) positive CML-CP from March 2002-February 2015. All the patients had baseline complete blood count, bone marrow examination with conventional cytogenetics and biochemistry. Baseline patient characteristics including age, gender, spleen size, total leucocyte count, platelet count, percentage of myeloblasts, basophils, and eosinophils in peripheral blood were recorded. Sokal score, Euro score, and EUTOS score were calculated according to formulas given below at baseline.

Sokal score $=\operatorname{Exp}\left[0.0116 \times(\right.$ age in years -43.4$)+0.0345 \times($ spleen size -7.51$)+0.1889\left([\text { platelet count } / 700]^{2}-0.563\right)+0.0887 \times($ blast cell counts - 2.10)], where Exp is the exponential function [5].

Euro score $=0.666($ when age $>50$ years $)+(0.042 \times$ spleen size $)+1.0956$ (when platelet count $\left.>1500 \times 10^{9} / \mathrm{L}\right)+(0.0584 \times$ blast cell counts $)+0.20399$ (when basophil counts $>3 \%)+(0.0413 \times$ eosinophil counts $) \times 100$ [6].

EUTOS score $=(7 \times$ basophils $)+(4 \times$ spleen size $)[7]$.

All the patients received imatinib 400mg daily as the first line therapy. Patients were monitored for their response or toxicity to imatinib and dose adjustments for toxicities were done as recommended [8]. In case of failure to achieve stated milestones as per ELN 2009 guidelines, patients were eligible to increase daily doses to $800 \mathrm{mg}$ [9]. Responses were defined as previously described by Kantarjian and colleagues [10]. Complete haematologic response (CHR) was defined as a white blood cell count of less than $10 \times 10^{9} / \mathrm{L}$, a platelet count of less than $450 \times 10 \%$ L, no immature cells (blasts, promyelocytes, or myelocytes) in the peripheral blood, and disappearance of all signs and symptoms related to leukaemia, including palpable splenomegaly. Conventional cytogenetics was performed in all cases on bone marrow cells at baseline, and subsequently six monthly to see for cytogenetic response which was identified as: complete cytogenetic response (CCyR), 0\% Ph-positive metaphases; partial cytogenetic response (PCyR), 1-35\% Ph-positive metaphases; major cytogenetic response (MCyR), 0-35\% Ph-positive metaphases; minor, 36-65\% Ph-positive metaphases; minimal, 66-95\% Ph-positive metaphases; or no response, greater than 95\% Ph-positive metaphases, according to ISCN 2013 nomenclature [11-12]. Real-time quantitative PCR (RQ-PCR) was performed on peripheral blood at baseline and after 6-12 monthly to look for molecular response which was defined as major molecular response $(\mathrm{MMR})$ if the $\mathrm{BCR}-\mathrm{ABL} / \mathrm{ABL}$ ratio was $<0.10 \%$ on the International Scale [13].

Progression to accelerated phase (CML-AP) was defined as blasts 10-19\% in peripheral blood (PB) or bone marrow (BM), basophils at least $20 \%$ in PB, persistent thrombocytopaenia unrelated to imatinib therapy, or persistent thrombocytosis unresponsive to imatinib therapy, and evidence of cytogenetic clonal evolution. For persistent grade 3/4 thrombocytopaenia after minimum four weeks of imatinib therapy, lasting beyond 2-4 weeks after drug withdrawal, repeat bone marrow evaluation was done to confirm disease progression. Progression to blast phase (CML-BP) was defined as at least $20 \%$ blasts in PB or BM, large foci or clusters of blasts in BM, and/or any extramedullary blast involvement, excluding spleen and liver. 
Statistical Package for Social Sciences 20 (SPSS inc., 233 South Wacker Drive, 11th floor, Chicago) was used for analysing the data. Cumulative incidence of CCyR and of MMR, progression-free survival (PFS), and overall survival (OS) were calculated with Kaplan-Meier method [14]. Different risk curves were compared with log-rank test [15].

\section{Results}

We identified 618 cases with CML-CP during the study period. Baseline characteristics for patients are shown in Table 1. Median age at presentation was 35 years with male: female ratio being 1.5:1.

Patient distribution according to risk groups is shown in Table 2. A total of $79(12.8 \%)$ of cases were low risk according to all the three scores while the corresponding number of high risk cases were $47(7.6 \%)$.

Cumulative incidence of CCyR and MMR according to all the three risk scores is shown in Table 3. Cumulative incidence of MMR was $82.3 \%, 81.7 \%$, and $79.7 \%$ respectively for Sokal, Euro, and EUTOS low risk scores. Difference between various risk groups according to all the three risk scores was statistically significant.

Kaplan-Meier analysis for PFS is shown in Figure 1. At a median follow-up at 56 months, estimated five years PFS for low, intermediate, and high risk Sokal scores were $92 \%, 93 \%$, and $73 \%$ respectively. Sokal score could not differentiate between those with low or intermediate scores $(P=0.68)$, however could significantly differentiate the high risk group $(P=0.002$ for low versus high risk, $P<0.0001$ for intermediate versus high risk). PFS for Euro score was $98 \%, 90 \%$, and $70 \%$ for low, intermediate, and high risk groups respectively. This score also could not differentiate low and intermediate risk groups significantly $(P=0.098)$, however the differences between low versus high risk $(P=0.001)$ and intermediate versus high risk $(P=0.006)$ were statistically significant. Low and high EUTOS scores showed PFS of $97 \%$ and $77 \%$ respectively with a significant $P$ value of $<0.0001$.

OS analysis for the three risk scores is shown in Figure 2. Estimated five years OS was $95 \%, 95 \%$, and $81 \%$ for low, intermediate, and high risk Sokal groups respectively. Here again the score could not differentiate between low and intermediate risk groups $(P=0.89)$, but could significantly differentiate the high risk group ( $P=0.015$ for both low versus high risk and for intermediate versus high risk). The corresponding OS for Euro risk scores was $99 \%, 94 \%$, and $76 \%$. Difference between low and intermediate risk groups was not statistically significant $(P=0.187)$. However, differences of that between low versus high $(P=0.002)$ and intermediate versus high risk $(P=0.005)$ groups were significant by this score. OS for low and high risk EUTOS scores was also significantly different being $97 \%$ and $83 \%$ respectively $(P<0.0001)$.

Table 1. Baseline characteristics.

\begin{tabular}{|l|c|}
\hline \multicolumn{1}{|c|}{ Data Variables } & Value \\
\hline Age, years; median (range) & $35(18-77)$ \\
\hline Gender, male : female & $1.5: 1$ \\
\hline Hb, gm/L; median (range) & $10.5(7-18)$ \\
\hline Platelet count, 10\%/L; median (range) & $399(130-1300)$ \\
\hline Peripheral blasts, \%; median (range) & $3(1-9)$ \\
\hline Eosinophils, \%; median (range) & $3(0-10)$ \\
\hline Basophils, \%; median (range) & $5(0-13)$ \\
\hline LDH, IU/L; median (range) & $964(339-2525)$ \\
\hline Spleen, cm; median (range) & $10(0-20)$ \\
\hline
\end{tabular}

Table 2. Patient distribution according to risk scores in present study.

\begin{tabular}{|l|c|c|c|}
\hline \multicolumn{1}{|c|}{ Risk Group } & Sokal Score & Euro Score & EUTOS Score \\
\hline Low, $\mathrm{n}(\%)$ & $128(20.7)$ & $125(20.2)$ & $393(64.1)$ \\
\hline Intermediate, $\mathrm{n} \mathrm{( \% )}$ & $355(57.4)$ & $385(62.3)$ & - \\
\hline High, $\mathrm{n}(\%)$ & $135(21.8)$ & $108(17.5)$ & $222(35.9)$ \\
\hline
\end{tabular}


Table 3. Predictive efficacy of the three score.

\begin{tabular}{|c|c|c|c|c|}
\hline Risk Score & Cumulative Incidence of CCyR (\%) & $P$ value & Cumulative Incidence of MMR (\%) & $P$ value \\
\hline \multicolumn{5}{|l|}{ (1) Sokal } \\
\hline Low & 88.5 & \multirow{3}{*}{$<0.001$} & 82.3 & \multirow{3}{*}{$<0.001$} \\
\hline Intermediate & 77 & & 70.4 & \\
\hline High & 51 & & 50.8 & \\
\hline \multicolumn{5}{|l|}{ (2) Euro } \\
\hline Low & 85 & \multirow{3}{*}{$<0.001$} & 81.7 & \multirow{3}{*}{$<0.001$} \\
\hline Inermediate & 75.6 & & 69.2 & \\
\hline High & 54.5 & & 49.4 & \\
\hline \multicolumn{5}{|l|}{ (3) EUTOS } \\
\hline Low & 85.6 & \multirow{2}{*}{$<0.001$} & 79.7 & \multirow{2}{*}{$<0.001$} \\
\hline High & 55 & & 50.7 & \\
\hline
\end{tabular}
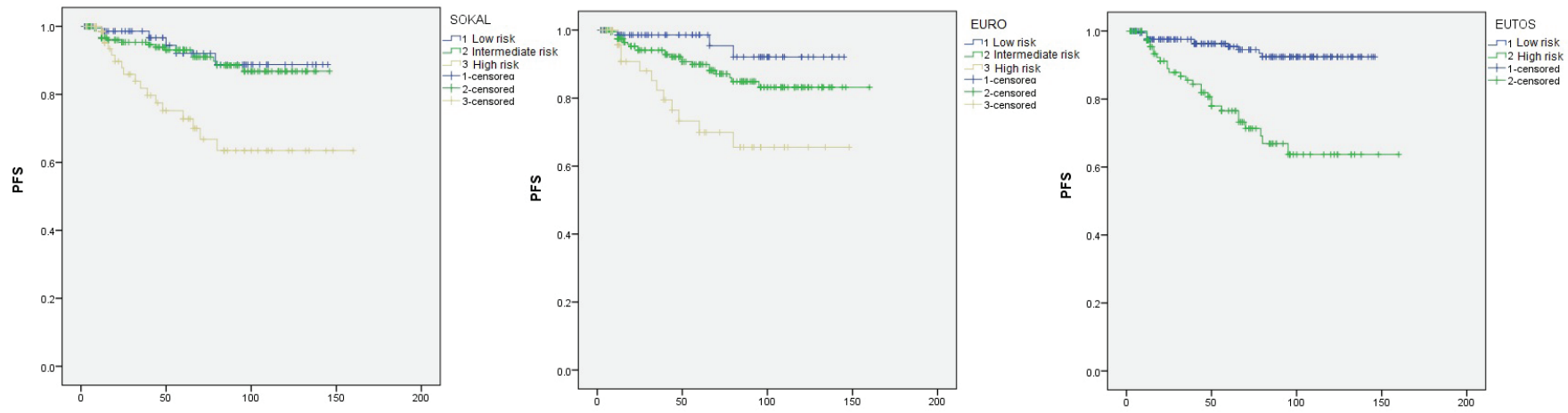

Figure 1. PFS analysis by Kaplan-Meier method.
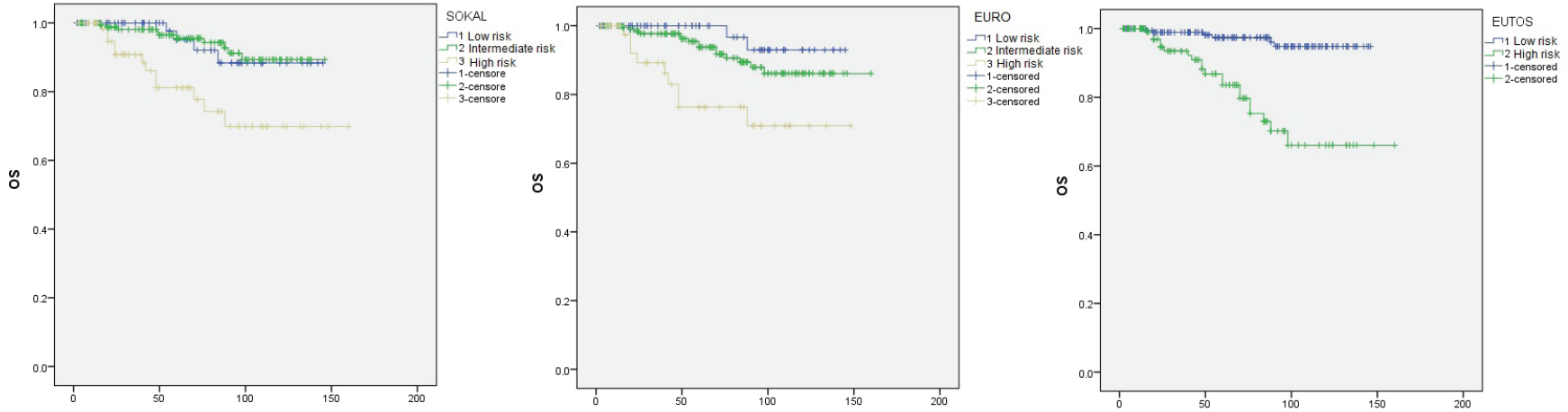

Figure 2. OS analysis by Kaplan-Meier method. 


\section{Discussion}

Attempts to better prognosticate CML-CP, the least aggressive form of the disease, at baseline have provided many variables over the years. Studies as early as in 1970s revealed that Ph negative disease had poorer outcomes than Ph positive disease [16]. Other unfavourable markers proposed included clinical features like fever, marked lymphadenopathy, and skin involvement. Whereaslaboratory parameters included increasing basophilia, myelofibrosis, multiple Philadelphia chromosomes, aneuploidy, muramidasuria, and rising leucocyte alkaline phosphatase values (associated with clinical deterioration) [17].

Attempts to identify the most accurate prediction model has provided us some of the useful risk prediction tools over the years which are summarised in Table 4. Initial systems of scoring, though simpler, had the limitation of small sample size which led to their limited applicability [18-21]. Later, the Sokal score developed in 1984 and the Hasford score developed in 1985 used larger populations for study and became widely applicable. The sophisticated calculators required for these scores are easily available now. However, the major limitation of these scores remains them being primarily validated for patients on busulphan and hydroxyurea (Sokal), or IFNa (Hasford) therapy. This made it imperative to re-evaluate their significance in the current era of TKI based first line therapy, but the results in various studies regarding this validation have been conflicting. EUTOS score is the most recent addition in this group which was specifically developed for patients on TKI treatment. The score is easy to calculate. However its major limitation remains the primary end point of CCyR at 18 months being taken as a predictor of PFS. This is because second generation TKIs can still improve survival outcomes in these cases not achieving CCyR at 18 months, and the most recent ELN guidelines recommend CCyR at six months as an optimal response [23]. EUTOS score has shown to effectively predict risk group at baseline in various studies [24-29]. However some studies have failed to show significant efficacy.

As is evident in Table 2, a variety of western populations were analysed in studies conducted for the Sokal, Euro, and EUTOS scores. Data on Asian population remains limited especially that in Indians. The Asian population supposedly harbours specific polymorphisms that affect sensitivity to TKI [30]. The disease also presents itself at a younger age than in western countries [31]. In our series, the median age at presentation was 35 years. Thus it remains important to assess how well these scores predict outcomes in our predominantly young adult population.

The distribution of cases according to risk groups in our study suggested a predominance of low and intermediate risk groups. This is in accordance with other studies, however proportionate cases with high risk were comparatively more. In the study by Hasford and colleagues, $39 \%, 37 \%$, and $24 \%$ of cases had low, intermediate, and high risk Sokal scores with corresponding Euro scores being $38 \%$, $51 \%$, and $11 \%$ [7]. EUTOS score was low for $90 \%$ and high for $10 \%$ in this study. The Japanese study also had lower proportionate cases of high risk with $18.6 \%, 8.9 \%$, and $11 \%$ cases with Sokal, Euro, and EUTOS high risk [2].

While attempting to address the question of which of the scores predicts best the response to imatinib in our population, we found that all the three scores effectively predicted cumulative incidence of CCyR and MMR. They also significantly prognosticated PFS and OS in our population. While Sokal score and Euro score could not significantly differentiate between low and intermediate risk groups when predicting PFS and OS, they could still significantly differentiate high risk group from low/intermediate risk group. A study in the Nigerian population done by Oyekunle and colleagues also suggested that predictive efficacy for PFS remained poor for Sokal score between the low and intermediate risk groups, however, it could predict difference better between low + intermediate versus high risk groups [32]. Another study from China on the other hand had the limitation of inability to differentiate low and intermediate risk groups reflected in prediction of OS, not PFS [33].

EUTOS score remained most accurate for prognosticating PFS and OS for its two risk groups in our analysis. Various other studies comparing EUTOS score with the previous scores are summarised in Table 5. The two studies from UK and Japan showed inadequate efficacy of EUTOS as a prognostic marker [34, 2]. These studies, however, had a relatively small number of cases classified as EUTOS high risk group, being $31(10 \%)$ and $16(11 \%)$ respectively in the two studies. The largest study by Kantarjian and colleagues shows superiority of EUTOS score in imatinib treated European population with similar results in Chinese study [7, 33]. 
Table 4. Risk tools in CML.

\begin{tabular}{|c|c|c|c|c|}
\hline Risk Tool & Risk Factors & Risk Groups & $\begin{array}{l}\text { a) Population, } \\
\text { b) Treatment used }\end{array}$ & $\begin{array}{l}\text { Predictive/Prognostic } \\
\text { Implication }\end{array}$ \\
\hline $\begin{array}{l}\text { Tura et al (1981) } \\
\text { [18] }\end{array}$ & $\begin{array}{l}\text { Factors: } \\
\text { 1. Splenomegaly }>15 \mathrm{~cm} \text { below costal margin, } \\
\text { 2. Hepatomegaly }>6 \mathrm{~cm} \text { below costal margin } \\
\text { 3. Thrombocytopaenia }<50 \times 10^{9} / / \text { or } \\
\text { thrombocytosis }>500 \times 10^{9} / l \\
\text { 4. Leucocytosis }>100 \times 10^{9} / l \\
\text { 5. Blasts in peripheral blood }>1 \% \\
\text { 6. Promyelocytes and myelocytes peripheral } \\
\text { blood }>20 \%\end{array}$ & $\begin{array}{l}\text { Stage I (low risk): } \\
0-1 \text { factor } \\
\text { Stage II } \\
\text { (intermediate risk): } \\
\text { 2-3 factors } \\
\text { Stage III (high risk): } \\
4-6 \text { factors }\end{array}$ & $\begin{array}{l}\text { a) } 255 \text { cases } \\
\text { b) Chemotherapy }\end{array}$ & $\begin{array}{l}\text { OS significantly different } \\
\text { between three groups } \\
(p<0.0005)\end{array}$ \\
\hline $\begin{array}{l}\text { Cervantes et al } \\
(1982) \text { [19] }\end{array}$ & $\begin{array}{l}\text { 1. Splenomegaly } \\
\text { 2. Hepatomegaly } \\
\text { 3. Erythroid precursors in peripheral blood } \\
\text { 4. Myeloblasts in bone marrow }>5 \%\end{array}$ & $\begin{array}{l}\text { Stage I (low risk): } \\
0-1 \text { factor } \\
\text { Stage II (intermedi- } \\
\text { ate risk): } 2 \text { factors } \\
\text { Stage III (high risk): } \\
\text { 3-4 factors }\end{array}$ & $\begin{array}{l}\text { a) } 121 \text { cases, Spain } \\
\text { b) Busulfan }\end{array}$ & $\begin{array}{l}5 \text { year OS } \\
\text { Stage } 1-70 \% \\
\text { Stage } 1 \mathrm{I}-30 \% \\
\text { Stage } \mathrm{III}-15 \%\end{array}$ \\
\hline $\begin{array}{l}\text { Kantarjian et al } \\
\text { (1990) [20] }\end{array}$ & $\begin{array}{l}\text { 1. Age } \geq 60 \\
\text { 2. Blasts in peripheral blood } \geq 3 \% \\
\text { 3. Blasts in bone marrow } \geq 5 \% \\
\text { 4. Basophils in peripheral blood } \geq 7 \% \\
5 \text {. Basophils in bone marrow } \geq 3 \% \\
6 \text {. Platelet count } \geq 700 \times 10^{9} / \mathrm{L} \\
\text { 7. Splenomegaly } \geq 10 \mathrm{~cm} \text { below costal margin } \\
\text { Accelerated phase: } \\
\text { a) Blasts in peripheral blood } \geq 15 \% \\
\text { b) Basophils in peripheral blood } \geq 20 \% \\
\text { c) Blasts and promyelocytes in peripheral } \\
\text { blood } \geq 30 \% \\
\text { d) Platelet count } \leq 100 \times 10^{9} / \mathrm{L} \\
\text { e) Cytogenetic clonal development }\end{array}$ & $\begin{array}{l}\text { Stage I: } \\
0-1 \text { factor } \\
\text { Stage II: } \\
2 \text { factors } \\
\text { Stage III: } \\
3 \text { or more factors } \\
\text { Stage IV: } \\
\text { accelerated phase }\end{array}$ & $\begin{array}{l}\text { a) } 406 \text { cases } \\
\text { b) Chemotherapy }\end{array}$ & $\begin{array}{l}\text { Median OS } \\
\text { Stage I-56 months } \\
\text { Stage II-45 months } \\
\text { Stage III-30 months } \\
\text { Stage IV-30 months }\end{array}$ \\
\hline $\begin{array}{l}\text { Kantarjian et al } \\
\text { (1985) [21] }\end{array}$ & $\begin{array}{l}\text { 1. Circulating basophils } \\
\text { 2. Basophils in bone marrow } \\
\text { 3. Race } \\
\text { 4. Age } \\
\text { 5. Additional chromosome abnormalities }\end{array}$ & $\begin{array}{l}\text { Low risk- } \mathrm{HR}<0.8 \\
\text { Intermediate risk- } \mathrm{HR} \\
0.8 \text { to } 1.39 \\
\text { High risk- } \mathrm{HR}>1.39\end{array}$ & $\begin{array}{l}\text { a) } 303 \text { cases } \\
\text { b) Busulphan or hydroxy- } \\
\text { urea or OAP (vincristine, } \\
\text { cytarabine, predniso- } \\
\text { lone) + anthracycline or } \\
\text { cyclophosphamide or } \\
\text { splenomegaly }\end{array}$ & $\begin{array}{l}\text { Median OS: } \\
\text { Low risk- } 53 \text { months } \\
\text { Intermediate risk- } \\
39 \text { months } \\
\text { High risk- } 25 \text { months }\end{array}$ \\
\hline $\begin{array}{l}\text { Sokal score } \\
\text { (1984) [5] }\end{array}$ & $\begin{array}{l}\text { 1. Age } \\
\text { 2. Spleen size below costal margin }(\mathrm{cm}) \\
\text { 3. Platelet count } \\
\text { 4. Blasts in peripheral blood }(\%)\end{array}$ & $\begin{array}{l}\text { Low risk: }<0.8 \\
\text { Intermediate risk: } \\
0.8-1.2 \\
\text { High risk: }>1.2\end{array}$ & $\begin{array}{l}\text { a) } 813 \text { cases, Europe, USA } \\
\text { b) Busulfan or } \\
\text { hydroxyurea }\end{array}$ & $\begin{array}{l}\text { OS at two years: } \\
\text { Low risk- } 90 \% \\
\text { High risk- } 65 \%\end{array}$ \\
\hline $\begin{array}{l}\text { Hasford score } \\
(1996)[22]\end{array}$ & $\begin{array}{l}\text { 1. Age } \\
\text { 2. Spleen size below costal margin }(\mathrm{cm}) \\
\text { 3. Erythroblasts in peripheral blood }(\%) \\
\text { 4. Eosinophils in peripheral blood }(\%) \\
\text { 5. Gender }\end{array}$ & $\begin{array}{l}\text { Low risk: }<1.4 \\
\text { Intermediate risk: } \\
1.4-2.0 \\
\text { High risk: }>2.0\end{array}$ & $\begin{array}{l}\text { a) } 490 \text { cases, Germany } \\
\text { b) Busulphan, hydroxyurea, } \\
\text { IFNa }\end{array}$ & $\begin{array}{l}\text { Five years OS: } \\
\text { Low risk- } 90 \%\end{array}$ \\
\hline
\end{tabular}


Table 4. Continued.

\begin{tabular}{|c|c|c|c|c|}
\hline $\begin{array}{l}\text { Euro score } \\
(1998)[6]\end{array}$ & $\begin{array}{l}\text { 1. Age } \\
\text { 2. Spleen size below costal margin (cm) } \\
\text { 3. Blasts in peripheral blood }(\%) \\
\text { 4. Eosinophils in peripheral blood }(\%) \\
\text { 5. Basophils in peripheral blood }(\%) \\
\text { 6. Platelet count }\end{array}$ & $\begin{array}{l}\text { Low risk: } \leq 780 \\
\text { Intermediate risk: }> \\
780 \leq 1480 \\
\text { High risk: }>1480\end{array}$ & $\begin{array}{l}\text { a) } 1303 \text { cases, Europe, } \\
\text { Japan, USA } \\
\text { b) IFNa }\end{array}$ & $\begin{array}{l}\text { Median OS: } \\
\text { Low risk- } 98 \text { months } \\
\text { Intermediate risk- } 65 \text { months } \\
\text { High risk- } 42 \text { months }\end{array}$ \\
\hline $\begin{array}{l}\text { EUTOS score } \\
(2011)[7]\end{array}$ & $\begin{array}{l}\text { 1. Basophils in peripheral blood }(\%) \\
\text { 2. Spleen size below costal margin }(\mathrm{cm})\end{array}$ & $\begin{array}{l}\text { Low risk: } \leq 87 \\
\text { High risk: }>87\end{array}$ & $\begin{array}{l}\text { a) } 2060 \text { cases, Europe } \\
\text { b) TKI (imatinib } 400 \mathrm{mg} / \mathrm{d} \\
\text { in } 41 \% \text { cases, imatinib } \\
400 \mathrm{mg} / \mathrm{d}+\mathrm{LDAC} \text { or IFNa } \\
\text { in } 34 \% \text { cases, imatinib } \\
600-800 \mathrm{mg} / \mathrm{d} \text { in } 25 \% \text { cases }\end{array}$ & $\begin{array}{l}\text { CCyR at } 18 \text { months: } \\
\text { Low risk- } 86 \% \\
\text { High risk- } 66 \% \\
\text { PFS at five years: } \\
\text { Low risk- } 90 \% \\
\text { High risk- } 82 \%\end{array}$ \\
\hline
\end{tabular}

IFNa- interferon alpha, LDAC- low dose cytosine arabinoside

Table 5. Comparison studies of Sokal, Euro and EUTOS scores in imatinib era.

\begin{tabular}{|l|l|l|}
\hline \multicolumn{1}{|c|}{ Reference } & \multicolumn{1}{|c|}{ Predictive Implication } & \multicolumn{1}{c|}{ Prognostic Implication } \\
\hline Marin et al (UK) [34] & $\begin{array}{l}\text { EUTOS not predictive of CCyR, MMR. } \\
\text { Sokal has predictive efficacy. }\end{array}$ & $\begin{array}{l}\text { EUTOS not prognostic of PFS, OS. Sokal } \\
\text { has prognostic efficacy. }\end{array}$ \\
\hline $\begin{array}{l}\text { Yamamoto et al } \\
\text { (Japan) [2] }\end{array}$ & $\begin{array}{l}\text { EUTOS not predictive of CCyR or MMR. } \\
\text { Sokal and Euro have predictive efficacy. }\end{array}$ & $\begin{array}{l}\text { EUTOS not prognostic of EFS, PFS, OS. } \\
\text { Sokal and Euro have prognostic efficacy. }\end{array}$ \\
\hline $\begin{array}{l}\text { Hasford et al } \\
\text { (Europe) [7] }\end{array}$ & $\begin{array}{l}\text { EUTOS better predictive of CCyR. Sokal } \\
\text { or Euro do not have predictive efficacy. }\end{array}$ & $\begin{array}{l}\text { EUTOS better prognostic of PFS. Sokal or } \\
\text { Euro do not have prognostic efficacy. }\end{array}$ \\
\hline Tao et al (China) [33] & $\begin{array}{l}\text { EUTOS better predictor of CCyR. Sokal } \\
\text { and Euro unable to differentiate intermedi- } \\
\text { ate Vs high risk for CCyR. }\end{array}$ & $\begin{array}{l}\text { EUTOS better prognostic of PFS and } \\
\text { OS. Sokal unable to differentiate low Vs } \\
\text { intermediate risk for OS. Euro unable to } \\
\text { differentiate intermediate Vs high risk for } \\
\text { PFS and OS. }\end{array}$ \\
\hline Present study (India) & $\begin{array}{l}\text { EUTOS, Sokal, and Euro scores predictive } \\
\text { of cumulative incidence of CCyR and MMR }\end{array}$ & $\begin{array}{l}\text { EUTOS better predictor of PFS and OS. } \\
\text { Sokal and Euro unable to differentiate low } \\
\text { and intermediate risk for PFS and OS. }\end{array}$ \\
\hline
\end{tabular}

Another important question which we have not addressed here remains if these scores can be used in scenarios where second generation TKIs are planned as first line therapy. Kantarjian and colleagues suggested that nilotinib could improve CCyR and MMR rates at 24 months across all Sokal risk groups in ENESTnd study [35]. Similarly dasatinib improved MMR rates at 24 months across all Hasford risk groups in DASASION study [36]. Jabbour and colleagues suggested that for patients treated with second generation TKIs, EUTOS score could predict CCyR but not MMR [37]. They also found no prognostic effect on survival. Recently bosutinib also showed improved MMR rates at 12 months across all Sokal risk groups in BELA study [38].

Many additional factors might have an impact on outcomes in patients with CML including patient compliance to therapy, racial differences, presence of additional cytogenetic abnormalities (ACA) such as major route abnormalities, altered imatinib pharmacokinetics e.g. OCT-1 transporter activity and imatinib plasma levels, bcr-abl1 mRNA transcript e.g. e13a2 or e14a2 and early treatment responses. It cannot be overemphasised that consideration of all these factors is important while attempting prognostication and prediction of response to treatment in CML patients on TKI therapy. Also using a homogenous end point for response to therapy that also includes the effect of second line TKI as well as using uniform therapy will be essential for future prospective studies in this regard. Further research in this direction remains imperative including use of novel biomarkers that could help in treatment decisions including choice of first line therapy for further improvement in disease outcomes. 
Our data confirms the utility of all the three scores in predicting response to imatinib. However, being a dichotomous variable and showing the ability to significantly differentiate between both risk groups in terms of PFS and OS, the EUTOS score appears to outperform as a prognostic model compared to the Sokal and Euro scores in Indian patients in this imatinib era.

\section{Conclusion}

Sokal, Euro, and EUTOS scores have significant predictive efficacy in the Indian population with CML-CP in the imatinib era. However the EUTOS score outperforms as a prognostic model in this scenario. We hope that ongoing research will help us identify better prognostic models to risk stratify patients and tailor therapy according to risk category in the future.

\section{Conflicts of interest}

The authors declare no conflicts of interest.

\section{Acknowledgments}

The authors would like to acknowledge Dr Malay Shah for his contribution to this study.

\section{References}

1. Galton DAG (1969) Chemotherapy of chronic myelocytic leukemia Sem Hematol 6(4) 323

2. Yamamoto E et al (2014) European treatment and outcome study score does not predict imatinib treatment response and outcome in chronic myeloid leukemia patients Cancer Sci 105(1) 105-109 DOI: 10.1111/cas.12321 PMID: 24450386 PMCID: 4317875

3. Yahng SA et al (2014) Prognostic discrimination for early chronic phase chronic myeloid leukemia in imatinib era: comparison of Sokal, Euro, and EUTOS scores in Korean population Int J Hematol 100(2) 132-140 DOI: 10.1007/s12185-014-1600-4 PMID: 24879034

4. Than $\mathrm{H}$ et al (2012) The EUTOS score is highly predictive for clinical outcome and survival in Asian patients with early chronic phase chronic myeloid leukemia treated with imatinib Blood 120 (ASH abstract no. 3758)

5. Sokal JE et al (1984) Prognostic discrimination in "good-risk" chronic granulocytic leukemia Blood 63(4) 789-99 PMID: 6584184

6. Hasford $\mathrm{J}$ et al (1998) A new prognostic score for survival of patients with chronic myeloid leukemia treated with interferon alfa. Writing Committee for the Collaborative CML Prognostic Factors Project Group J Nat/ Cancer Inst 90(11) 850-8 DOI: 10.1093/jnci/90.11.850 PMID: $\underline{9625174}$

7. Hasford $\mathrm{J}$ et al (2011) Predicting complete cytogenetic response and subsequent progression-free survival in 2060 patients with CML on imatinib treatment: the EUTOS score Blood 118(3) 686-92 DOI: 10.1182/blood-2010-12-319038 PMID: 21536864

8. Deininger MW et al (2003) Practical management of patients with chronic myeloid leukemia receiving imatinib $\mathrm{J}$ Clin Oncol 21(8) 1637-47 DOI: 10.1200/JCO.2003.11.143 PMID: 12668652

9. Baccarani $\mathrm{M}$ et al (2009) Chronic myeloid leukemia: an update of concepts and management recommendations of European LeukemiaNet J Clin Oncol 27(35) 6041-51 DOI: 10.1200/JCO.2009.25.0779 PMID: 19884523 PMCID: $\underline{4979100}$

10. Kantarjian $\mathrm{H}$ et al (2002) Hematologic and cytogenetic responses to imatinib mesylate in chronic myelogenous leukemia $N$ Engl J Med. 346(9) 645-52 DOI: 10.1056/NEJMoa011573 PMID: 11870241 
11. Baccarani M, Pane F and Saglio G (2008) Monitoring treatment of chronic myeloid leukemia Haematologica; 93(2) 161-9 DOI: 10.3324/haematol.12588 PMID: 18245647

12. LG Shaff er et al (eds) (2013) An International System for Human Cytogenetic Nomenclature

13. Hughes $\mathrm{T}$ et al (2006) Monitoring CML patients responding to treatment with tyrosine kinase inhibitors: review and recommendations for harmonizing current methodology for detecting BCR-ABL transcripts and kinase domain mutations and for expressing results Blood 108(1) 28-37 DOI: $10.1182 /$ blood-2006-01-0092 PMID: 16522812 PMCID: 1895821

14. Kaplan GL and Meier P (1958) Nonparametric estimation from incomplete observations J Am Stat Assoc 53457 DOI: 10.1080/01621459.1958.10501452

15. Peto R and Pike MC (1973) Conservation of the approximation I(O - E)2/E in the log rank test for survival data on tumor inci-

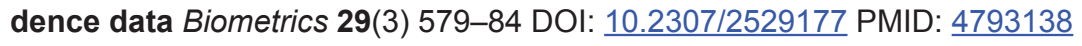

16. Ezdinli EA et al (1970) Philadelphia-chromosome-positive and negative chronic myelocytic leukemia Ann Intern Med 72(2) 175-82 DOI: $\underline{10.7326 / 0003-4819-72-2-175}$ PMID: $\underline{5263036}$

17. Theologides A (1972) Unfavourable signs in patients with chronic myelocytic leukemia Ann Intern Med 76(1) 95-9 DOI: 10.7326/0003-4819-76-1-95 PMID: $\underline{4555534}$

18. Tura S, Baccarani M and Corbelli G (1981) Staging of chronic myeloid leukaemia Br J Haematol 47(1) 105-119 DOI: $10.1111 /$ j.1365-2141.1981.tb02765.x PMID: $\underline{6934007}$

19. Cervantes $F$ and Rozman C (1982) A multivariate analysis of prognostic factors in chronic myeloid leukemia Blood 60(6) 1298-1304 PMID: $\underline{6958336}$

20. Kantarjian HM et al (1990) Proposal for a simple synthesis prognostic staging system in chronic myelogenous leukemia Am $J$ Med 88(1) 1-8 DOI: 10.1016/0002-9343(90)90119-X PMID: 2294759

21. Kantarjian HM et al (1985) Chronic myelogenous leukemia: a multivariate analysis of the associations of patient characteristics and therapy with survival Blood 66(6) 1326-35 PMID: $\underline{3864497}$

22. Hasford J et al (1996) Analysis and validation of prognostic factors for CML. German CML Study Group Bone Marrow Transplant 17 (Suppl 3) S49-54 PMID: 8769702

23. Baccarani $\mathrm{M}$ et al (2013) European LeukemiaNet recommendations for the management of chronic myeloid leukemia Blood 122(6) 871-84 DOI: 10.1182/blood-2013-05-501569

24. Uz B et al (2013) EUTOS CML prognostic scoring system predicts ELN-based 'event-free survival' better thanEuro/ Hasford and Sokal systems in CML patients receiving front-line imatinibmesylate Hematology 18(5) 247-52 DOI: 10.1179/1607845412Y.0000000071 PMID: 23540886

25. Tiribelli M et al (2013) EUTOS score predicts long-term outcome but not optimal response to imatinib in patientswith chronic myeloid leukaemia Leuk Res 37(11) 1457-60 DOI: 10.1016/j.leukres.2013.07.037 PMID: 23993428

26. Hoffmann VS et al (2013) The EUTOS prognostic score: review and validation in 1288 patients withCML treated frontline with imatinib Leukemia 27(10) 2016-22 DOI: 10.1038/leu.2013.171 PMID: 23752173

27. Breccia $\mathrm{M}$ et al (2012) The EUTOS score identifies chronic myeloid leukeamia patients with poor prognosis treated with imatinib first or second line Leuk Res 36(9) e209-10 DOI: 10.1016/j.leukres.2012.05.011 PMID: 22770911

28. Tiribelli M et al (2012) EUTOS scoreidentifies cases with poor outcome in patients with early chronic phase chronic myeloid leukemia, though not predictive for optimal response to imatinib In:ASH Annual Meeting Abstract 1203778

29. Bonifacio $\mathrm{M}$ et al (2014) EUTOS score predicts early optimal response to imatinib according to the revised 2013 ELN recommendations Ann Hematol 93(1) 163-4 DOI: 10.1007/s00277-013-1974-z 
30. Singh $O$ et al (2012) SLC22A1-ABCB1 haplotype profiles predict imatinib pharmacokinetics in Asian patients with chronic myeloid leukemia PLoS ONE 7(12) e51771 DOI: 10.1371/journal.pone.0051771 PMID: 23272163 PMCID: 3525665

31. Bansal S, Prabhash K and Parikh P (2013) Chronic myeloid leukemia data from India Indian J Med Paediatr Oncol 34(3) 154-8 DOI: $10.4103 / 0971-5851.123711$

32. Oyekunle AA et al (2012) The predictive value of the Sokal and Hasford scoring systems in chronic myeloid leukaemia in the imatinib era $J$ Hemat Malignancies 2(2) 25-32

33. Tao Z et al (2014) EUTOS score predicts survival and cytogenetic response in patients with chronic phase chronic myeloid leukemia treated with first-line imatinib Leuk Res 38(9) 1030-5 DOI: 10.1016/j.leukres.2014.06.006 PMID: 24996976

34. Marin D, Ibrahim AR and Goldman JM (2011) European Treatment and Outcome Study (EUTOS) score for chronic myeloid leukemia still requires more confirmation J Clin Oncol 29(29) 3944-5 DOI: 10.1200/JCO.2011.37.6962 PMID: 21900102

35. Kantarjian $\mathrm{HM}$ et al (2011) Nilotinib versus imatinib for the treatment of patients with newly diagnosed chronic phase, Philadelphia chromosome-positive, chronic myeloid leukaemia: 24-month minimum follow-up of the phase 3 randomised ENESTnd trial Lancet Oncol 12(9) 841-51 DOI: 10.1016/S1470-2045(11)70201-7 PMID: 21856226

36. Kantarjian HM et al (2012) Dasatinib or imatinib in newly diagnosed chronic-phase chronic myeloid leukemia: 2-year follow-up from a randomized phase 3 trial (DASISION) Blood 119(5) 1123-9 DOI: 10.1182/blood-2011-08-376087

37. Jabbour E et al (2012) EUTOS score is not predictive for survival and outcome in patients with early chronic phase chronic myeloid leukemia treated with tyrosine kinase inhibitors: a single institution experience Blood 119(19) 4524-6 DOI: 10.1182/ blood-2011-10-388967 PMID: 22431574 PMCID: $\underline{362365}$

38. Cortes JE et al (2012) Bosutinib versus imatinib in newly diagnosed chronic-phase chronic myeloid leukemia: results from the BELA Trial J Clin Oncol 30(28) 3486-92 DOI: 10.1200/JCO.2011.38.7522 PMID: 22949154 PMCID: 4979199 